\title{
X-Linked Emery-Dreifuss Muscular Dystrophy: Study Of X-Chromosome Inactivation and Its Relation with Clinical Phenotypes in Female Carriers
}

\author{
Emanuela Viggiano ${ }^{1}$, Agnieszka Madej-Pilarczyk ${ }^{2}$, Nicola Carboni ${ }^{3}{ }^{\circledR}$, Esther Picillo ${ }^{1}$, \\ Manuela Ergoli ${ }^{1}$, Stefania del Gaudio ${ }^{4}$, Michal Marchel ${ }^{5}$, Gerardo Nigro ${ }^{6}$, Alberto Palladino ${ }^{1}$ \\ and Luisa Politano ${ }^{1, *}$ \\ 1 Cardiomyology and Medical Genetics, Department of Experimental Medicine, University of Campania, \\ 80138 Naples, Italy \\ 2 Neuromuscular Unit, Mossakowski Medical Research Centre, Polish Academy of Sciences, 00-901 Warsaw, \\ Poland \\ 3 Neurology Department, Hospital San Francesco of Nuoro, 08100 Nuoro, Italy \\ 4 Department of Experimental Medicine, University of Campania, 80138 Naples, Italy \\ 5 Department of Cardiology, Medical University of Warsaw, 02-091 Warsaw, Poland \\ 6 Chair of Cardiology, University of Campania-Monaldi Hospital, 80131 Napoli, Italy \\ * Correspondence: luisa.politano@unicampania.it; Tel.: +39-081-566-5300; Fax: +39-081-566-5101
}

Received: 25 September 2019; Accepted: 7 November 2019; Published: 11 November 2019

\begin{abstract}
X-linked Emery-Dreifuss muscular dystrophy (EDMD1) affects approximately 1:100,000 male births. Female carriers are usually asymptomatic but, in some cases, they may present clinical symptoms after age 50 at cardiac level, especially in the form of conduction tissue anomalies. The aim of this study was to evaluate the relation between heart involvement in symptomatic EDMD1 carriers and the $\mathrm{X}$-chromosome inactivation $(\mathrm{XCI})$ pattern. The $\mathrm{XCI}$ pattern was determined on the lymphocytes of 30 symptomatic and asymptomatic EDMD1 female carriers-25 familial and 5 sporadic cases-seeking genetic advice using the androgen receptor (AR) methylation-based assay. Carriers were subdivided according to whether they were above or below 50 years of age. A variance analysis was performed to compare the XCI pattern between symptomatic and asymptomatic carriers. The results show that $20 \%$ of EDMD1 carriers had cardiac symptoms, and that $50 \%$ of these were $\geq 50$ years of age. The XCI pattern was similar in both symptomatic and asymptomatic carriers. Conclusions: Arrhythmias in EDMD1 carriers poorly correlate on lymphocytes to a skewed XCI, probably due to (a) the different embryological origin of cardiac conduction tissue compared to lymphocytes or (b) the preferential loss of atrial cells replaced by fibrous tissue.
\end{abstract}

Keywords: Emery-Dreifuss muscular dystrophy (EDMD1); X-chromosome inactivation (XCI); cardiac symptoms; skewed $\mathrm{X}$-chromosome inactivation

\section{Introduction}

X-linked Emery-Dreifuss muscular dystrophy (OMIM 310300; EDMD1) affects about 1:100,000 males. It is caused by mutations in the EDMD1 gene [1,2], which encodes the emerin protein-a component of the inner nuclear membrane in the muscles (skeletal, smooth, and cardiac muscle) and other tissues including skin and blood (leukocytes) [3-5]. The phenotype is characterized by triad joint contractures (elbows, Achilles tendons, and posterior cervical muscles), humeroperoneal muscle weakness, and cardiac involvement as conduction disturbances [6-12]. Although female carriers of EDMD1 are usually asymptomatic, they can sometimes present clinical symptoms such as cardiac arrhythmias, including atrial fibrillation or atrioventricular (AV) block [3,13-18]. These can lead to 
sudden cardiac death $[19,20]$. There are no data available on the prevalence of symptoms in female EDMD1 carriers, although cardiac symptoms seem to correlate with age [13]. On the contrary, no peripheral myopathy and contractures have been reported [19]. It has been suggested that cardiac symptoms in EDMD1 carriers depend on the deficiency of the emerin protein in the nuclei of cells [3]. Previous studies have demonstrated decreased levels of emerin in muscles, skin, leukocytes, and lymphoblastoid cell lines [3,4]. However, a reduction of around $50 \%$ in protein was not associated with symptoms [4], while reductions of $>95 \%$ were observed in symptomatic carriers [3]. It has also been suggested that the amount of protein reduction may depend on skewed X-chromosome inactivation (XCI) $[3,14]$. However, only one study has reported the analysis of XCI in EDMD1 carriers, and only one was symptomatic among them [3].

We reported the results of XCI analysis in EDMD1 carriers to study the potential role of skewed $\mathrm{XCI}$ in the pathogenesis of cardiac symptoms. In particular, we tested 30 EDMD1 carriers and analyzed the results observed in symptomatic compared to asymptomatic subjects.

\section{Subjects and Methods}

\subsection{Subjects}

Thirty EDMD1 carriers, 25 from 9 families and 5 females related to sporadic cases, were included in the study. The diagnosis of the EDMD1 carrier was based on the family history and confirmed by molecular analysis in familial and sporadic cases. Mutations in the EMD gene are shown in Table 1.

Table 1. Clinical and genetic data, and X-chromosome inactivation (XCI) ratios in Emery-Dreifuss muscular dystrophy (EDMD1) carriers, are analyzed. XCw: X-chromosome wild-type; AV: atrioventricular.

\begin{tabular}{|c|c|c|c|c|c|}
\hline $\begin{array}{l}\text { Family } \\
\text { Number }\end{array}$ & ID Subject & $\begin{array}{c}\text { Age at Last } \\
\text { Control (Years) }\end{array}$ & XCw Inactivation (\%) & Signs/Symptoms & EMD Mutation \\
\hline \multicolumn{6}{|c|}{ N. 1} \\
\hline I-1 & 5327 & 58 & 54.0 & $1^{\text {st }}$ degree $\mathrm{AV}$ block & c. $130 \mathrm{C}>\mathrm{T}$ \\
\hline I-2 & 5328 & 51 & 49 & no & \\
\hline I-4 & 5325 & 49 & 30 & no & \\
\hline I-3 & 5326 & 47 & 70 & no & \\
\hline II-2 & 5322 & 28 & 28 & no & \\
\hline \multicolumn{6}{|c|}{ N. 2} \\
\hline I-1 & 4811 & 32 & 35.4 & no & c. $564-565 \mathrm{del} \mathrm{CT}$ \\
\hline I-2 & 4810 & 24 & 40.7 & no & \\
\hline $\mathrm{I}-3$ & 4809 & 21 & 49.7 & no & \\
\hline \multicolumn{6}{|c|}{ N. 3} \\
\hline I-1 & 9265 & 50 & 64.8 & no & c. $1 \mathrm{~A}>\mathrm{G}$ \\
\hline $\mathrm{I}-3$ & 9266 & 46 & 41.9 & no & \\
\hline II-1 & 9264 & 31 & 65.5 & no & \\
\hline II-2 & 9267 & 25 & 50.9 & no & \\
\hline \multicolumn{6}{|c|}{ N. 4} \\
\hline I-1 & 9577 & 52 & 91.8 & $1^{\text {st }}$ degree AV block & $\begin{array}{l}\text { c. IVS4+2G>Cc. } \\
399+2 G>C\end{array}$ \\
\hline II-2 & 9261 & 35 & 44.8 & no & \\
\hline I-5 & 9262 & 22 & 34.3 & no & \\
\hline I-6 & 9263 & 20 & 0 & no & \\
\hline \multicolumn{6}{|c|}{ N. 5} \\
\hline IV-1 & 9259 & 29 & n.i. & no & c. $153 \mathrm{delC}$ \\
\hline III-3 & 9258 & 53 & 89.2 & no & \\
\hline III-4 & 9257 & 49 & 50. & no & \\
\hline
\end{tabular}


Table 1. Cont.

\begin{tabular}{|c|c|c|c|c|c|}
\hline $\begin{array}{l}\text { Family } \\
\text { Number }\end{array}$ & ID Subject & $\begin{array}{c}\text { Age at Last } \\
\text { Control (Years) }\end{array}$ & XCw Inactivation (\%) & Signs/Symptoms & EMD Mutation \\
\hline \multicolumn{6}{|c|}{ N. 6} \\
\hline II-1 & 9269 & 37 & 40.7 & no & c. 451dup \\
\hline II-2 & 9270 & 25 & 68.9 & no & \\
\hline \multicolumn{6}{|c|}{ N. 7} \\
\hline I-1 & 6418 & 42 & 90.8 & no & c. $106 \mathrm{~A}>\mathrm{T}^{* *}$ \\
\hline I-2 & 5008 & 40 & 70 & no & \\
\hline \multicolumn{6}{|c|}{ N. 8} \\
\hline I-1 & 2907 & 50 & 35.3 & $1^{\text {st }}$ degree AV block & c. $740 \mathrm{C}<\mathrm{T}^{* * *}$ \\
\hline \multicolumn{6}{|c|}{ N. 9} \\
\hline I-1 & 202 & 62 & 20 & Atrial fibrillation & c. $740 \mathrm{C}<\mathrm{T}^{* * *}$ \\
\hline Isolated Cases & ID Subject & $\begin{array}{c}\text { Age at Last } \\
\text { Control (Years) }\end{array}$ & XCw Inactivation (\%) & Cardiac Findings & EMDMutation \\
\hline 1 & 8581 & 50 & n.i. & no & c. $106 \mathrm{~A}>\mathrm{T}^{*}$ \\
\hline 2 & 9268 & 40 & 48.9 & no & c.192_192delinsTC \\
\hline 3 & 9256 & 44 & 78.8 & no & c.IVS3 -27del18 \\
\hline 4 & 9637 & 51 & 74.6 & $2^{\text {nd }}$ degree $\mathrm{AV}$ block & c.IVS2+1G>A \\
\hline 5 & 9578 & 51 & 18.7 & no & c. $256 \mathrm{C}>\mathrm{T}$ \\
\hline
\end{tabular}

The carriers were divided into two groups: symptomatic $(n=5)$ and asymptomatic $(n=25)$. Furthermore, the last group was subdivided by $<50$ or $\geq 50$ years of age, as arrhythmic events usually occur in EDMD1 carriers after the age of 50. The carriers were classified as symptomatic or asymptomatic according to the presence or absence of clinical symptoms, respectively. Muscle strength was assessed by manual muscle testing using the Medical Research Council (MRC) scale [21]. Heart involvement was investigated through a complete cardiological examination including standard electrocardiogram (ECG), $24 \mathrm{~h}$ Holter monitoring, and echocardiography. A prolonged PQ interval (the time from the onset of the $\mathrm{P}$ wave to the start of the QRS complex), a decreased amplitude of $\mathrm{P}$ wave, an increased dispersion of $\mathrm{P}$ wave, and the presence of atrial fibrillation/flutter, atrial or ventricular ectopic beats, or AV blocks of variable degrees, observed at the electrocardiogram; a sinus pause of $>2.5 \mathrm{~s}$, the presence of atrial fibrillation/flutter, atrial or ventricular ectopic beats, or AV blocks of variable degrees observed at the ECG Holter monitoring; increased atrial or ventricular dimensions, a reduced ejection fraction (EF; and wall motion abnormalities observed at the echocardiography were considered pathological.

On the contrary, we defined EDMD1 carriers who did not show any sign of muscle impairment, contractures, and/or cardiomyopathy as asymptomatic.

\subsection{Methods}

\subsubsection{DNA Analysis}

The peripheral blood was collected into tubes containing ethylenediaminetetraacetic acid (EDTA). Genomic DNA was extracted from leukocytes using the standard operating procedures (SOPs) established by the EuroBioBank Network and quantified spectrophotometrically. An amount of $1 \mu \mathrm{L}$ was electrophoresed in 1\% agarose gel to evaluate DNA integrity.

DNA samples were provided by the Naples Human Mutation Gene Biobank (NHMGB) genetic biobank of Cardiomyology and Medical Genetics, which is a member of EuroBioBank and the Telethon Network of Genetic Biobanks (TNGB).

At least one EDMD1-carrying male in each family was analyzed in order to differentiate between the mutant $(\mathrm{XCm})$ and wild-type $(\mathrm{XCw})$ alleles. All subjects, and/or a legal representative in the case of a minor, provided written informed consent to the study for blood collection, in accordance with 
the Declaration of Helsinki. The study was approved by the Ethical Committee of the University of Campania "Luigi Vanvitelli" (00923-16).

\subsubsection{X-Inactivation Assay}

The pattern of $X$-chromosome inactivation was determined as previously reported [22,23]. In particular, $500 \mathrm{ng}$ of genomic DNA samples was digested with 10 units HpaII and 10 units HhaII methylation-sensitive enzymes in $50 \mu \mathrm{L}$ of sterile distilled water at $37^{\circ} \mathrm{C}$ overnight. Then, $500 \mathrm{ng}$ from each of the 88 DNA samples were incubated overnight with the same volumes of buffer and distilled water as above but excluding enzymes as the control. Digested and undigested DNA samples were used as templates for the amplification of the androgen receptor (AR) in exon 1. The PCR was performed in a $25 \mu \mathrm{L}$ reaction volume composed of $2 \mu \mathrm{L}$ digested or undigested DNA, PCR buffer (10 $\mathrm{mM}$ Tris-HCl; $50 \mathrm{mM} \mathrm{KCl}$; $\mathrm{pH}$ 8.3), 5 pmol forward primer marked with the WellRED dye-labeled D4-PA at 5' (Sigma Aldrich, Milan, Italy), 5 pmol reverse primer, $1.5 \mathrm{mM} \mathrm{MgCl}_{2}, 0.5 \mathrm{mM}$ dNTP, and 0.3 U GoTaq DNA polymerase (Promega, Milan, Italy). The PCR conditions were as follows: $95^{\circ} \mathrm{C}$ for 5 min, $28 \times\left(95^{\circ} \mathrm{C}\right.$ for $30 \mathrm{~s}, 6{ }^{\circ} \mathrm{C}$ for $30 \mathrm{~s}, 72{ }^{\circ} \mathrm{C}$ for $\left.30 \mathrm{~min}\right)$, and $72{ }^{\circ} \mathrm{C}$ for $7 \mathrm{~min}$.

The sequences of the oligonucleotides used were as follows:

- $\quad$ Forward 5'-[D4-PA]TCCAGAATCTGTTCCAGAGCGTGC-3';

- Reverse 5'-ATGAGGAACAGCAACCTTCACAGC-3'.

To separate the two alleles, $1 \mu \mathrm{L}$ of PCR product was mixed with $38.5 \mu \mathrm{L}$ of Sample Loading Solution (Beckman, Fullerton, CA, USA) and $0.5 \mu \mathrm{L}$ of DNA Size Standard Kit 400. This standard included DNA fragments labeled with WellRED fluorescent dye of the following sizes: 60, 70, 80, 90, 100, 120, 140, 160, 180, 190, 200, 220, 240, 260, 280, 300, 320, 340, 360, 380, 400, and 420 nucleotides (Beckman, Fullerton, CA, USA). The mix was loaded on a 96-well plate and 1 drop of mineral oil was added to each well. The fragment analysis was performed by means of a Beckman CEQ 8000 Genetic Analysis System, using the Frag-3 run method. PCR products derived from the undigested DNA samples that gave 1 peak, similar to the CAG repeats, were considered uninformative for the analysis. The ratio between the two alleles (peak areas of allele 1 digested/undigested)/[(allele 1 peak digested/undigested) + (allele 2 digested/undigested) $] \times 100$ was used to analyze the distribution of XCI degree in our cohort of carriers. The higher peaks corresponding to the expected size of alleles were considered for the analysis, while the shorter peaks were considered polymerase artifacts (such as stutter and plus A peaks). The degree of XCw inactivation in the digested DNA in carriers with positive family history was calculated as follows: peak area of ( $\mathrm{XCw}$ digested/undigested $) /[\mathrm{XCw}$ digested/undigested $)+(\mathrm{XCm}$ digested/undigested $)] \times 100$. The allele 2 inactivation was calculated as follows: peak area of the (allele 2 digested/undigested)/[(allele 2 digested/undigested) + (allele 1 digested/undigested) $] \times 100$, considering the shorter as allele as allele 1 and the longer allele as allele 2 . The degree of XCI was defined as random when it showed values $\leq 60 \%$, skewed when the value was between $60 \%$ and $85 \%$, and extremely skewed when it was $>85 \%[24,25]$ (Figure 1).

\subsection{Statistical Analysis}

Fisher's exact test was used to compare the frequency of skewed XCI between carriers $<50$ or $\geq 50$ years of age. Between symptomatic and asymptomatic carriers, the values were expressed as mean \pm SEM. Significance was recognized when $p<0.05$. 
A

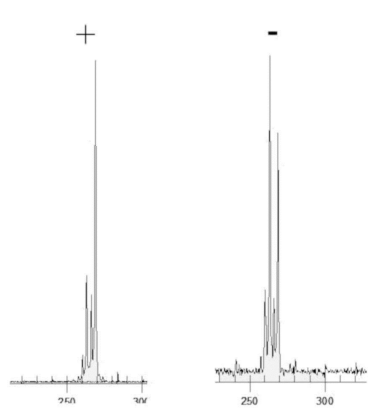

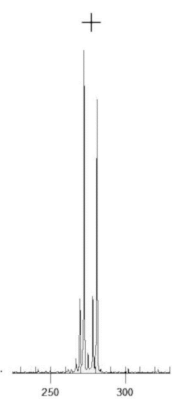

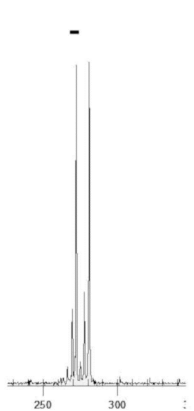

C

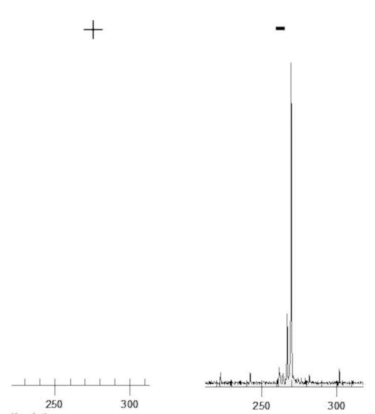

Figure 1. Gene scanner traces for HpaII digested (+) and undigested (-) DNA. The peak represents the amplified androgen receptor (AR) allele. The size of the allele is determined by the number of repeats within the $A R$ gene. The area under the peak indicates the degree of amplification of the alleles. The higher peaks correspond to the expected size of alleles, while the shorter peaks should be considered as artifacts. One carrier (A) presented a skewed XCI (20:80), while the other showed a random X-chromosome invitation (XCI) (B). The digested DNA sample of the Emery-Dreifuss muscular dystrophy (EDMD1) male (C) did not show a peak (negative control), while the undigested sample presented one peak.

\section{Results}

\subsection{Subjects}

Twenty five out of 30 EDMD1 carriers analyzed were from nine families (Figure 2) with a positive history for EDMD1, and at least one male affected available. Five carriers were sporadic subjects further included in the analysis, for which it was impossible to differentiate XCw. Five families were from Italy (Sardinia and South Italy) and four were from Poland. Out of the 30 carriers, 10 were $\geq 50$ years of age. The clinical data of the subjects, mutations in the EMD gene, and the results of the XCI for familial and sporadic cases are shown in Table 1.

The average age of familial carriers was $39.1 \pm 2.5$ years. The average age of sporadic cases, all mothers of affected males, was $47.2 \pm 2.2$ years. The average age of symptomatic carriers of both familial and isolated cases was $54.6 \pm 2.3$ years, compared to $37.6 \pm 2.2$ years of those without symptoms. No carrier $<50$ years of age was symptomatic. Out of 10 carriers $\geq 50$ years of age, 50\% presented cardiac involvement in the form of an AV block of first or second degree $(n=4)$, or atrial fibrillation $(n=1)$. The carrier with ID 9637 in the isolated case's group was implanted with a pacemaker due to a second degree of AV block.

Twelve mutations in the EMD gene were found in our cohort. Of these, nine are already reported in the UMD-EMD database (http:/www.umd.be/EMD/). Two novel mutations were reported by our research team in previous papers [26,27], while one new mutation, c. 564-565 del CT, has not previously been published.

\subsection{Analysis of XCI}

Two carriers were not included in the analysis because they were uninformative. The X-inactivation pattern calculated as the ratio between allele 1 and allele 2 followed a normal distribution with a peak at 40-49 (Figure 3) in EDMD1 carriers. The frequency of skewed or extremely skewed XCI in our cohort of carriers was $35.7 \%$, or 10 out of 28 . In particular, $31.5 \%$ of carriers were $<50$ years of age, while $44.4 \%$ were $\geq 50$ years of age. 


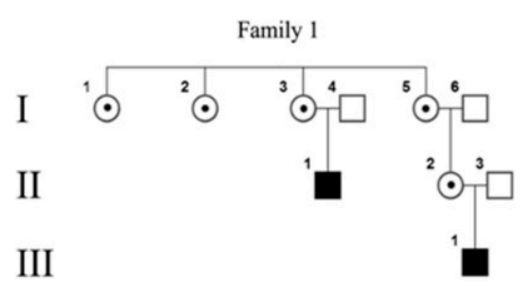

Family 4

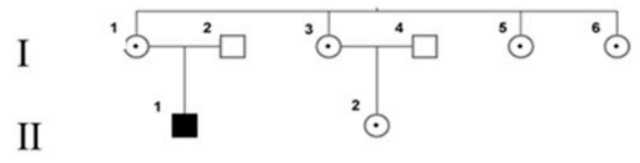

III

IV

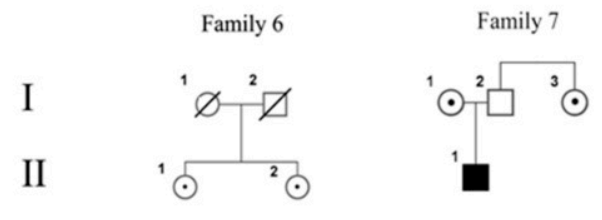

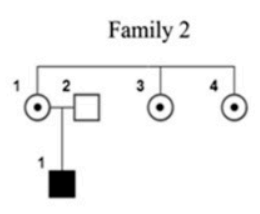

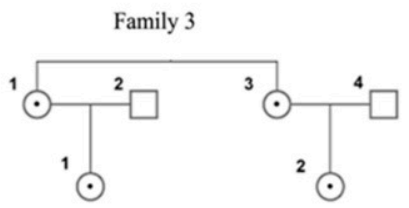

Family 5
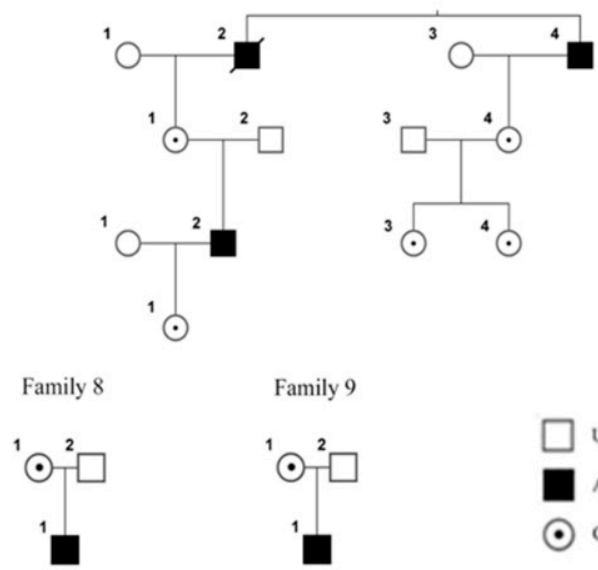

Unaffected male

a Affectod male

- Carrier female

III

Figure 2. Pedigree of EDMD1 families. Please note that only carriers included in the study are shown.

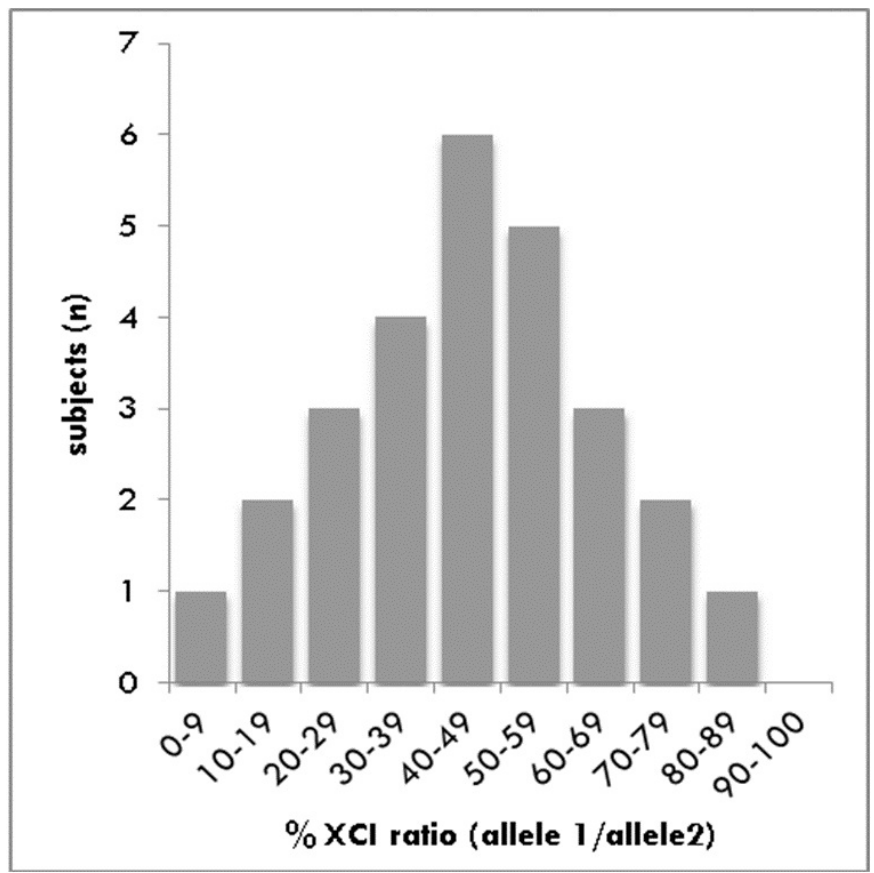

Figure 3. Distribution of XCI ratios in EDMD1 carriers. Normal distribution of the XCI pattern in the leukocytes from the analyzed EDMD1 carriers. 


\subsection{Statistical Differences}

No significant differences in the frequency of skewed XCI between EDMD1 carriers $<50$ or $\geq 50$ years of age were found $(p=0.06)$, nor between asymptomatic versus symptomatic carriers $(p=0.2)$.

\section{Discussion}

EDMD1 carriers usually do not present symptoms. Very few studies can be found in related literature reporting anecdotal cases of symptomatic carriers, in particular, at the cardiac level [19]. Heart involvement in both affected males and carriers is characterized by the occurrence of conduction defects, such as tachyarrhythmias (ectopic beats, atrial flutter, and fibrillation) or bradyarrhythmias, such as sinoatrial or atrioventricular blocks, often requiring a pacemaker or defibrillator implantation. A higher prevalence of cardiac alterations can be observed in EDMD1 carriers $\geq 50$ years of age.

In this study, the reported data confirm that EDMD1 carriers do not present muscle symptoms but often develop cardiac conduction anomalies. In our group, cardiac abnormalities were observed in approximately $20 \%$ of cases when considered as a whole. However, focusing on the ages of the carriers, a higher prevalence (50\%) of cardiac disturbances-atrial fibrillation in one carrier, and an AV block of various degrees in four carriers-was observed in carriers $\geq 50$ years. This percentage is well above the figures of arrhythmias in the general population, in which a prevalence of about $2-3 \%$ for atrial fibrillation and $6-7 \%$ for atrioventricular blocks has been reported in the white population $\geq 60$ years of age [28-31].

Unaffected females in the general population show a normal distribution of the XCI pattern and skewed XCI increasing with age [32], with a prevalence of about $20-40 \%$ in females $\geq 50$ years of age $[32,33]$. Moreover, a skewed $\mathrm{XCI}$, with the preferential inactivation of the $\mathrm{XCW}$, seems to correlate with the development of clinical symptoms in female carriers of X-linked diseases, such as hemophilia B [34], dyskeratosis congenita [35], and Duchenne and Becker muscular dystrophies [36,37]. Some authors suggest that a skewed XCI could play a role in the EDMD1 carrier's clinical presentation $[3,15]$. Manilal et al. [3,4] demonstrated reduced levels of emerin from a Western bloting in lymphocytes, lymphoblastoid cell lines (LCL), muscles, and, by immunofluorescence, a mosaic pattern of emerin expression in skin biopsy [3,5]. However, in that study, the XCI analysis was performed on only one subject [3]. This study showed that cardiac symptoms in EDMD1 carriers are unrelated to a skewed XCI on lymphocytes. We found 10 out of $28(35.7 \%)$ cases of skewed or extremely skewed XCI with a growing trend with increasing age, in agreement with previous studies [32,33]. However, no significant correlation was found between age and skewed XCI pattern nor between symptomatic and asymptomatic EDMD1 carriers in our cohort.

To explain this apparent discordance between heart involvement and degree of the XCI in EDMD1 carriers, besides the already mentioned "age effect", the different embryological origin of cardiac conduction tissue compared with myocardium should be taken into account. In fact, cardiomyocytes originate as blood cells from the mesoderm germinal layer [38] and share a similar XCI pattern [39,40]. The conduction system consists of highly specialized cardiomyocytes, is innervated by cardiac ganglia, and presents a high number of fibroblasts. The latter derive from two different germinal layers (ectodermal and mesodermal) [38,41-43] exhibiting a different XCI pattern [39,40]. As cardiac symptoms in EDMD1 are prevalently supraventricular arrhythmias or atrioventricular blocks that involve the conduction tissue, we cannot exclude that the XCI pattern analyzed in leukocytes does not reflect that of the conduction tissue, unlike what we observed and reported in Duchenne and Becker carriers who present myocardial failure [23]. Furthermore, at least two more factors may play a role in the pathogenesis of cardiac disturbances in EDMD1 and explain our results: (1) the marked loss of atrial cells replaced by fibrous tissue [43-46], and (2) the intrinsic alterations of the conduction system where emerin is localized, in particular at the intercalated disks [47]. However, future studies on animal models are necessary to confirm our hypothesis.

A limitation of our study may be the small number of subjects analyzed to confirm these data and establish definite results. Another could be the failure to analyze the XCI pattern in cardiac 
conduction tissue obtained by endomyocardial biopsy, which was not performed due to ethical reasons. However, this paper represents the first analysis of XCI in a group of genetically confirmed EDMD1 female carriers.

Author Contributions: Conceptualization, L.P.; Data curation, E.V., N.C., E.P., M.E., M.M., G.N. and A.P.; Formal analysis, E.P. and M.E.; Investigation, E.V., A.M.P., M.M., G.N., A.P. and L.P.; Methodology, N.C., S.D.G. and L.P.; Project administration, L.P.; Resources, A.M.P., N.C., M.M., G.N. and A.P.; Supervision, L.P.; Validation, L.P.; Writing - original draft, E.V.; Writing - review \& editing, L.P.

Funding: This research received no external funding.

Acknowledgments: Several authors of this manuscript are members of the European Reference Network for rare neuromuscular diseases (ERN, EURO-NMD). We thank the Naples Human Mutation Genetic Biobank (NHMGB) of Cardiomyology and Medical Genetics, member of EuroBioBank and of the Telethon Network of Genetic Biobanks (TNGB) for providing us the DNA samples.

Conflicts of Interest: The authors declare no conflict of interest.

\section{References}

1. Bione, S.; Maestrini, E.; Rivella, S.; Mancini, M.; Regis, S.; Romeo, G.; Toniolo, D. Identification of a novel $\mathrm{X}$-linked gene responsible for Emery-Dreifuss muscular dystrophy. Nat. Genet. 1994, 8, 323-327. [CrossRef] [PubMed]

2. Blone, S.; Small, K.; Aksmanovic, V.M.; Morandi, L.; Kress, W.; Yates, J.R.; Warren, S.T.; Toniolo, D.; D’Urso, M.; Ciccodicola, A.; et al. Identification of new mutations in the Emery-Dreifuss muscular dystrophy gene and evidence for genetic heterogeneity of the disease. Hum. Mol. Genet. 1995, 4, 1859-1863. [CrossRef] [PubMed]

3. Manilal, S.; Manila, S.; Recan, D.; Sewry, C.A.; Hoeltzenbein, M.; Llense, S.; Leturcq, F.; Deburgrave, N.; Barbot, J.-C.; Man, N.T.; et al. Mutations in Emery-Dreifuss muscular dystrophy and their effects on emerin protein expression. Hum. Mol. Genet. 1998, 7, 855-864. [CrossRef] [PubMed]

4. Manilal, S.; Sewry, C.; Man, N.T.; Muntoni, F.; Morris, G. Diagnosis of X-linked Emery-Dreifuss muscular dystrophy by protein analysis of leucocytes and skin with monoclonal antibodies. Neuromuscul. Disord. 1997, 7, 63-66. [CrossRef]

5. Mora, M.; Cartegni, L.; Di Blasi, C.; Barresi, R.; Bione, S.; Di Barletta, M.R.; Morandi, L.; Merlini, L.; Nigro, V.; Politano, L.; et al. X-linked emery-dreifuss muscular dystrophy can be diagnosed from skin biopsy or blood sample. Ann. Neurol. 1997, 42, 249-253. [CrossRef] [PubMed]

6. E Emery, A.; E Dreifuss, F. Unusual type of benign x-linked muscular dystrophy. J. Neurol. Neurosurg. Psychiatry 1966, 29, 338-342. [CrossRef] [PubMed]

7. Emery, A.E. Emery-Dreifuss muscular dystrophy-A 40 year retrospective. Neuromuscul. Disord. 2000, 10, 228-232. [CrossRef]

8. Carboni, N.; Mura, M.; Mercuri, E.; Marrosu, G.; Manzi, R.C.; Cocco, E.; Nissardi, V.; Isola, F.; Mateddu, A.; Solla, E.; et al. Cardiac and muscle imaging findings in a family with X-linked Emery-Dreifuss muscular dystrophy. Neuromuscul. Disord. 2012, 22, 152-158. [CrossRef] [PubMed]

9. Somma, S.; Comi, L.I.; Petretta, V.R.; Giugliano, M.A.M.; Limongelli, F.M.; Divitiis, O.; Nigro, G.; Politano, L.; Papparella, S.; Restucci, B.; et al. Structural Basis of Cardiomyopathy in Duchenne/Becker Carriers. Ann. N. Y. Acad. Sci. 1995, 752, 108-110.

10. Nigro, G.; Russo, V.; Rago, A.; Papa, A.A.; Carbone, N.; Marchel, M.; Palladino, A.; Hausmanowa-Petrusewicz, I.; Russo, M.G.; Politano, L. Regional and transmural dispersion of repolarisation in patients with Emery-Dreifuss muscular dystrophy. Kardiol. Pol. 2012, 70, 1154-1159. [PubMed]

11. Russo, V.; Rago, A.; Politano, L.; Papa, A.A.; Di Meo, F.; Russo, M.G.; Golino, P.; Calabrò, R.; Nigro, G. Increased dispersion of ventricular repolarization in emery dreifuss muscular dystrophy patients. Med. Sci. Monit. 2012, 18, CR643-CR647. [CrossRef] [PubMed]

12. E Buckley, A.; Dean, J.; Mahy, I.R. Cardiac involvement in Emery Dreifuss muscular dystrophy: A case series. Heart 1999, 82, 105-108. [CrossRef] [PubMed]

13. Bialer, M.G.; McDaniel, N.L.; Kelly, T.E. Progression of cardiac disease in emery-dreifuss muscular dystrophy. Clin. Cardiol. 1991, 14, 411-416. [CrossRef] [PubMed]

14. Sakata, K.; Shimizu, M.; Ino, H.; Yamaguchi, M.; Terai, H.; Fujino, N.; Hayashi, K.; Kaneda, T.; Inoue, M.; Oda, Y.; et al. High Incidence of Sudden Cardiac Death with Conduction Disturbances and Atrial 
Cardiomyopathy Caused by a Nonsense Mutation in the STA Gene. Circulation 2005, 111, 3352-3358. [CrossRef] [PubMed]

15. Peretto, G.; Di Resta, C.; Perversi, J.; Forleo, C.; Maggi, L.; Politano, L.; Barison, A.; Previtali, S.C.; Carboni, N.; Brun, F.; et al. Cardiac and Neuromuscular Features of Patients with LMNA-Related Cardiomyopathy. Ann. Intern. Med. 2019, 171, 458. [CrossRef] [PubMed]

16. Wang, S.; Peng, D. Cardiac Involvement in Emery-Dreifuss Muscular Dystrophy and Related Management Strategies. Int. Heart J. 2019, 60, 12-18. [CrossRef] [PubMed]

17. Faiella, W.; Bessoudo, R. Cardiac manifestations in Emery-Dreifuss muscular dystrophy. Can. Med. Assoc. J. 2018, 190, E1414-E1417. [CrossRef] [PubMed]

18. Arbustini, E.; Di Toro, A.; Giuliani, L.; Favalli, V.; Narula, N.; Grasso, M. Cardiac Phenotypes in Hereditary Muscle Disorders. J. Am. Coll. Cardiol. 2018, 72, 2485-2506. [CrossRef] [PubMed]

19. Fishbein, M.C.; Siegel, R.J.; Thompson, C.E.; Hopkins, L.C. Sudden death of a carrier of X-linked Emery-Dreifuss muscular dystrophy. Ann. Intern. Med. 1993, 119, 900-905. [CrossRef] [PubMed]

20. Dickey, R.P.; Ziter, F.A.; Smith, R.A. Emery-Dreifuss muscular dystrophy. J. Pediatr. 1984, 104, 555-559. [CrossRef]

21. London Medical Research Council (L.M.R.). Aids to the Examination of the Peripheral Nervous System-Medical Research Council Memorandum No. 45; London Her Majesty's Stationery Office: London, UK, 1976.

22. Allen, R.C.; Zoghbi, H.Y.; Moseley, A.B.; Rosenblatt, H.M.; Belmont, J.W. Methylation of HpaII and HhaI sites near the polymorphic CAG repeat in the human androgen-receptor gene correlates with $\mathrm{X}$ chromosome inactivation. Am. J. Hum. Genet. 1992, 51, 1229-1239. [PubMed]

23. Viggiano, E.; Picillo, E.; Cirillo, A.; Politano, L. Comparison of X-chromosome inactivation in Duchenne muscle/myocardium-manifesting carriers, non-manifesting carriers and related daughters. Clin. Genet. 2013, 84, 265-270. [CrossRef] [PubMed]

24. Ørstavik, K.H. X chromosome inactivation in clinical practice. Hum. Genet. 2009, 126, 363-373. [CrossRef] [PubMed]

25. Ørstavik, K.H. Skewed X inactivation in healthy individuals and in different diseases. Acta Paediatr. 2006, 95, 24-29. [CrossRef] [PubMed]

26. Brunl, P.; Polltano, L.; Plluso, G.; Cappa, V.; Covone, A.E.; Nigro, V.; Ciccodicola, A.; Romeo, G.; D’Urso, M. SSCP detection of novel mutations in patients with Emery-Dreifuss muscular dystrophy: Definition of a small C-terminal region required for emerin function. Hum. Mol. Genet. 1995, 4, 2003-2004.

27. Nigro, G.; Russo, V.; Ventriglia, V.M.; Della Coppa, N.; Palladino, A.; Nigro, V.; Calabrò, R.; Nigro, G.; Politano, L. Early onset of cardiomyopathy and primary prevention of sudden death in X-linked Emery-Dreifuss muscular dystrophy. Neuromuscul. Disord. 2010, 20, 174-177, Epub 2010 Feb 10. [CrossRef] [PubMed]

28. Go, A.S.; Hylek, E.M.; A Phillips, K.; Chang, Y.; Henault, L.E.; Selby, J.V.; Singer, D.E. Prevalence of diagnosed atrial fibrillation in adults: National implications for rhythm management and stroke prevention: The AnTicoagulation and Risk Factors in Atrial Fibrillation (ATRIA) Study. JAMA 2001, 285, 2370-2375. [CrossRef] [PubMed]

29. Upshaw, C.B. Comparison of the prevalence of first-degree atrioventricular block in African-American and in Caucasian patients: An electrocardiographic study III. J. Natl. Med. Assoc. 2004, 96, 756-760. [PubMed]

30. Lindberg, T.; Bohman, D.M.; Elmstahl, S.; Jogréus, C.; Berglund, J.S. Prevalence of unknown and untreated arrhythmias in an older outpatient population screened by wireless long-term recording ECG. Clin. Interv. Aging 2016, 11, 1083-1090. [CrossRef] [PubMed]

31. Heeringa, J.; Van Der Kuip, D.A.; Hofman, A.; Kors, J.A.; Van Herpen, G.; Stricker, B.H.; Stijnen, T.; Lip, G.Y.; Witteman, J.C. Prevalence, incidence and lifetime risk of atrial fibrillation: The Rotterdam study. Eur. Heart J. 2006, 27, 949-953. [CrossRef] [PubMed]

32. Busque, L.; Mio, R.; Mattioli, J.; Brais, E.; Blais, N.; LaLonde, Y.; Maragh, M.; Gilliland, D. Nonrandom $\mathrm{X}$-inactivation patterns in normal females: Lyonization ratios vary with age. Blood 1996, 88, 59-65. [CrossRef] [PubMed]

33. El Kassar, N.; Hetet, G.; Brière, J.; Grandchamp, B. X-chromosome inactivation in healthy females: Incidence of excessive lyonization with age and comparison of assays involving DNA methylation and transcript polymorphisms. Clin. Chem. 1998, 44, 61-67. [PubMed] 
34. Espinós, C.; I Lorenzo, J.; Casaña, P.; Martínez, F.; Aznar, J.A. Haemophilia B in a female caused by skewed inactivation of the normal X-chromosome. Haematologica 2000, 85, 1092-1095. [PubMed]

35. Devriendt, K.; Matthijs, G.; Legius, E.; Schollen, E.; Blockmans, D.; Van Geet, C.; Degreef, H.; Cassiman, J.J.; Fryns, J.P. Skewed X-chromosome inactivation in female carriers of dyskeratosis congenita. Am. J. Hum. Genet. 1997, 60, 581-587. [PubMed]

36. Viggiano, E.; Picillo, E.; Politano, L. DMD Phenotype in Girls with a de novo Balanced X;3 Autosome Translocation: A Case Report. J. Genet. Syndr. Gene Ther. 2013, 4, 2.

37. Juan-Mateu, J.; Rodríguez, M.J.; Nascimento, A.; Jimenez-Mallebrera, C.; González-Quereda, L.; Rivas, E.; Paradas, C.; Madruga, M.; Sanchez-Ayaso, P.; Jou, C.; et al. Prognostic value of X-chromosome inactivation in symptomatic female carriers of dystrophinopathy. Orphanet J. Rare Dis. 2012, 7, 82. [CrossRef] [PubMed]

38. Yutzey, K.E.; Kirby, M.L. Wherefore heart thou? Embryonic origins of cardiogenic mesoderm. Dev. Dyn. 2002, 223, 307-320. [CrossRef] [PubMed]

39. Azofeifa, J.; Cremer, M.; Waldherr, R. X-chromosome methylation ratios as indicators of chromosomal activity: Evidence of intraindividual divergencies among tissues of different embryonal origin. Hum. Genet 1996, 97, 330-333. [CrossRef] [PubMed]

40. Fialkow, P.J. Primordial cell pool size and lineage relationships of five human cell types. Ann. Hum. Genet. 1973, 37, 39-48. [CrossRef] [PubMed]

41. Kirby, M.L.; Stewart, D.E. Neural crest origin of cardiac ganglion cells in the chick embryo: Identification and extirpation. Dev. Boil. 1983, 97, 433-443. [CrossRef]

42. Virágh, S.; E Challice, C. The development of the conduction system in the mouse embryo heart. II. Histogenesis of the atrioventricular node and bundle. Dev. Boil. 1977, 56, 397-411. [CrossRef]

43. Jongbloed, M.R.M.; Mahtab, E.A.F.; Blom, N.A.; Schalij, M.J.; Groot, A.C.G.-D. Development of the Cardiac Conduction System and the Possible Relation to Predilection Sites of Arrhythmogenesis. Sci. World J. 2008, 8, 239-269. [CrossRef] [PubMed]

44. Hara, H.; Nagara, H.; Mawatari, S.; Kondo, A.; Sato, H. Emery-Dreifuss muscular dystrophy. An autopsy case. J. Neurol. Sci. 1987, 79, 23-31. [CrossRef]

45. Waters, D.D.; Nutter, D.O.; Hopkins, L.C.; Dorney, E.R. Cardiac Features of an Unusual X-Linked Humeroperoneal Neuromuscular Disease. N. Engl. J. Med. 1975, 293, 1017-1022. [CrossRef] [PubMed]

46. Voit, T.; Krogmann, O.; Lenard, H.; Neuen-Jacob, E.; Wechsler, W.; Goebel, H.; Rahlf, G.; Lindinger, A.; Nienaber, C. Emery-Dreifuss Muscular Dystrophy: Disease Spectrum and Differential Diagnosis. Neuropediatrics 1988, 19, 62-71. [CrossRef] [PubMed]

47. Cartegni, L.; Di Barletta, M.R.; Barresi, R.; Squarzoni, S.; Sabatelli, P.; Maraldi, N.; Mora, M.; Di Blasi, C.; Cornelio, F.; Merlini, L.; et al. Heart-specific localization of emerin: New insights into Emery-Dreifuss muscular dystrophy. Hum. Mol. Genet. 1997, 6, 2257-2264. [CrossRef] [PubMed] 